(НЕ)ПОЗНАТИЯТ ЕЗИК: КОЛЕДА ПРИ БЕСАРАБСКИТЕ БЪЛГАРИ

СВЕТЛАНА ГЕОРГИЕВА

ОДЕСКИ НАЦИОНАЛЕН УНИВЕРСИТЕТ „ИЛЯ МЕЧНИКОВ“- УКРАЙНА

sgeorgijevamititel@gmail.com

\title{
THE (UN)KNOWN LANGUAGE: CHRISTMAS IN BESSARABIAN BULGARIANS
}

\section{SVETLANA GEORGIEVA}

ODESSA NATIONAL UNIVERSITY “Ilya MECHNIKOV” - UKRAINE

sgeorgijevamititel@gmail.com

Folk terminology expresses the national specificity of cultures and its investigation is promising in the context of the emerging trends in the European thinking from the beginning of the XXI century. The article explores Christmas customs and rituals in an ethnolinguistic perspective, analyses a Christmas blessing, which is a verbal component of customs and rituals performed at Christmas, and provides a description of the linguistic features of an artistic ritual text. Christmas (Kòlda (A, Vch), Kòl'da (Z, Kul), Kòl'eda (Kam), Kòlada (Dl, A, Kr, Kub), Kòl'ada (Kub), Kòlida (S) is the richest winter religious holiday-ritual complex of Bessarabian Bulgarians. It is celebrated over three days (6-8 January) and is dedicated to the birth of Christ, also known as the Nativity of Christ (25.XII). This study is an attempt at systemising and exploring the features of the cultural dialect related to the Christmas ritual, the linguistic means used at all levels of the language system and their functioning in the artistic practice over the generations.

Keywords: Christmas, Christmas customs and rituals, Christmas blessing, ethnolinguistics, cultural dialect of a Bulgarian, Bulgarian diaspora in Ukraine

Традиционната календарно-празнична система на населението от Южна Украйна съставлява съществен и интересен дял от етнокултурното наследство на българите. В нея са съхранени множество езически и християнски по своя произход и съдържание възгледи и представи и предопределените от тях обреди и обичаи. Изучаването на езиковите сведения на народната култура е една от актуалните задачи на съвременното езикознание, най-напред на диалектологията и етнолингвистиката. Езикът е неделима част от културата на всеки етнос. Той е и извор, основа за разкриване на етнокултурната история и етническата специфика на всеки народ. В българската езиковедска наука съществуват редица разработки, посветени 
на календарните и семейните обреди и обичаи на българите, в които е събран и систематизиран голям масив от диалектни названия (Легурска, Китанова/Legurska, Kitanova 2008). Календарните празници като фактор, съдействащ за запазването на етнокултурната идентичност на българите от Украйна, са богат извор за разкриване на българската народна култура, за промените, които тя търпи в обкръжението на други култури (Георгиева/ Georgieva 2017: 56-69).

Като отправна точка за това изследване служи трудът на Н. С. Державин „Болгарскія колоніи в Россіи (Таврическая, Херсонская и Бессарабская губерніи)“ (1914). Теренните материали, събрани от съвременните изследователи (Барболова, Колесник/Barbolova, Kolesnik 1998; Барболова/Barbolova 1999; Барболова/Barbolova 2013; Колесник/Kolesnik 2008; Георгиева/Georgieva 2015; Георгиева/Georgieva 2016; Георгиева/Georgieva 2017), частично са въведени в научните изследвания и представляват основа за по-цялостни и комплексни проучвания, които ще дадат нови данни за българския език и култура.

Сред преселническите български говори в Южна Украйна са представени основно говорите от североизточния (мизийски), южнобалканския, подбалканския и източнотракийския тип. Установено е, че преселническите български говори се делят на: чушмелийски, чийшийски, балкански, олшански, тракийски, западнобългарски и източнородопски (Георгиева/Georgieva 2011: 91-96; Георгиева/Georgieva 2013: 29-36; Георгиева, Колесник/Georgieva, Kolesnik 2016: 5-42).

Целта на изследването е да се систематизират и проучат диалектните материали, свързани с коледната обредност, средствата от всички равнища на езиковата система, както и начините, по които те функционират в художествената практика на поколенията.

Обект на етнолингвистичния анализ са основно лични теренни изследвания на автора, записани диалектни текстове и календарен обреден фолклор. Предмет на това изследване са коледните обичаи и обреди на бесарабските българи.

Независимо от многобройните исторически превратности бесарабските българи поддържат етническото си самосъзнание, език, традиции и вярвания. Обредните текстове, донесени от България, са се предавали от поколение на поколение без съществени промени в текста. Като висша комуникативна единица текстовете, построени по определен езиков модел, са не само фон за анализ на стилистичните възможности на езиковите единици от всички езикови равнища, а са преди всичко цялостен речеви феномен, който се характеризира със структурно, семантично и функционално единство.

Коледа, Божик, Божич, Бодник, Голяма Коледа, Колада, Коляда, Коленда, Коледня, Колядня, Рождество, Рождество Христово е най-богатият в обредно отношение зимен празник и един от най-големите годишни празници, познат в цялата българска етническа територия (КПОБ/КРОВ 
2000: 16). Празник в деня, когато църквата отбелязва Рождество Христово. Названието си получава от древните римски Календи, посветени на зимното сльнцестоене (БМ/ВМ 1994: 172). Връзката му с този повратен момент в природата определя богатството на празничната обредност и мястото му в народния календар. Според християнския мит Коледа е денят на раждането на младия Бог, откъдето идва и другото му название Божсич, Божик (БМ/ВМ 1994: 172). Коледуването е обичай, който влиза в празнично-обредния комплекс на Коледа. Коледните празници и свързаните с тях обреди са чакани от бесарабските българи с голяма радост заради техния силен емоционален заряд. Изпълнявани повсеместно в миналото, в найново време те отново се възраждат.

Ко̀лда (А, Вч), Ко̀л’да (3, Кул), Ко̀л'еда (Кам), Ко̀лада (Дл, А, В, Кр, Куб), Ко̀л'ада (Куб), Ко̀лида (С), Гул'а́мъ Ко́л'еда (Чш) е най-големият и най-богат в обредно отношение зимен религиозен празнично-обреден комплекс на бесарабските българи, който се празнува три дни (6-8 януари) и е посветен на раждането на Христос, поради което е известен и като Рождество Христово (25.XII). (Державин/Derzhavin 1914: 171) / 7.0I.

[// Кол'да са празнува три д’ена (06.-08.01). // Ду Кол'да б’аши n'ет н'едил'и пост / се ткъф кту и за Виликд'ен (ни са иде м'есу / мулочну / риба / ица). // На сришту празнику са коли прас'е // са прайат луканки / бахур (пич'онучну) / крава̀ной / салтисон. // (Кул) // Коладн'ии'ит'е кажд'ий в'ечар и'ал м'ес'аи вм'есту с Кудата са тр'ин'ируаха. Им пумагаха двама най-стар'и мъжуй, д'ету хубуу знайат кол'едарск'ит'и n'есн'и. Са п'ейат най-разн'и п'есн'и: за мума, за ирг'ен, за малку д'ит'е, за хаз 'айан. (3) // На Колада 7 йанвар'а, ората си готв'ат убави манджи. Готв'ат рану сабал'ана у собата. У собата са пулучават най убави манджи. Готви са за три д'ена ду колада. Свикэрвата си испруважда младити с ина манджа у сват'ата си.(Ор) // Гул'а́мъ Ко́л'еда/ о́d’ъm ирг'е́ни пу ч'е́тири / ш'ес / питна́йси ду́ши// Ръково́ди стънини́к. // П'е́йъm/ Утвур'е́ти зла́тни по́рти // П'е́йът на хъз'а́инъ// Ирг'е́нити зи́мът кръва́й/ нъ кръва́й / куко́шкъ/ убръ'штът къди́ кун'ъ́mъ / и ч'етъ́m блъгуслув'е́йе // Утско́ги бо́жи дъ пумо́жи// И ко́куту дзвизди́ ф си́н'у н'е́би/ то́лкувъ здра́ви ф та́а къ́шть // Дар'а́вът ги / руббли / къп'е́йки / мисо́ / слъни́на / бръшно́ / фъсу́л/ лук / вйну / и о́рий // На уб'а́m тр'а́бъ дъ и́ма сви́нску // Хъз'а́инъ със жсина́ / ути́вът дъ плашъ́m пло́дно дърво́ // Жъ руди́ш ли то́а гуди́нъ / и́ли дъ тъ утсичъ' // Нид'е́ú гу сичи́ / жъ руди́ / утгувар 'ъ' жинить // Три д'е́н'а о́рътъ празну́вът // О́д'ат нъ го́сти / нъ уро́ (Чш) // На пѐрва̀ дѐн на Колада са прави милина. Дувадат Капри. Каприти убл ѐчѐни с високи шапки. На шапкити имат пира гулѐми. Мумити права̀т кравай, вичартъ ода̀m да пѐа̀m. По-малкити лапита дувадат сас зв езди. На тос празник са готви аладѐи, зѐли и урис, картошка, ини 'а, булгур (B)].

Главният обред се извършва на Бъдни вечер (Легурска, Китанова/Legurska, Kitanova 2008: 45-48]. Вечерята започва с прекадяване на цялата 
къща. Прекадяването се осмисля като средство за предпазване, за прогонване на злите и нечисти сили. Прекадените храни и предмети на трапезата (и около нея) придобиват особена магическа сила, която се прибавя към присъщите им символни значения. Цялата вечер е свързана с различни гадания за бъдеща женитба, за здраве и благополучие. Среднощ тръгват коледарите (=Кол'да).

Бъдн'и в'еч'ар (във всички бесарабски български села), Бадни вечер (T), Кадена вечар (3), Святой вечир (3), Сришту Ко̀л’да (Г, Зд), Малка Колда (Чш) - народен празник - вечерта срещу Кол’да - на 6 срещу 7 януари, когато цялото семейство се събира на тържествена вечеря.

[// Прибират ф къити// Хаз'айката са управа / прай сичката рабута ду уб'ет// В ч'аса три-ч'етари дицата /пет-идинайси години/ закач'ат да ходат да кул'едуват / фл'ават ф каж'ан двор и викат// Кул'едай, кул'едай!/ Хаз'айката ги ср'ашта / им дава имиш / куиту кулидари са п'ерви в двору / тийа с'адат на кул'аниа / коту да л'агат кукошкити// Кту найнапр'аш духадат мумичиниа / хаз'айката дума// Ши имами кукошки!// кту мумч'енца// Ши имами пит'ели!/ (Кул)// Са готви житу кут'а'/ кампот ут сушнак/ посни мании// Са пич'е л'ап/ утгор'а му пра'ат прусурки// Вич'ер'ата са прикад 'ава с там'ан// Ц'ала нош в лампатката ду кун'ата гури ог'ан (3)// На Бъдни в'еч'ер са прави милина// Дувадат капри// Каприти убл'еч'ени с високи шапки// На шапкити имат пира гул'еми// Мумити прав 'ат краваи вичарт'е од 'ат да п'е'ат// По-малкити лапита дувадат сас зв'езди// На тос празник са готви алд'еи/ з'ели и урис/ картошка/ ини'а/ булгур (В)// На Ма́лка Ко́лида го́тв'ъm пъча́/ ма́ндж'ъ/ чу́шки/ гу́шки// Из с'е́лу тръ́гвът кулида́ри/ и ви́кат// Сла́вити ли Бо́га// Усми́хнати хъз'а́йкити ги пуср'а́штът/ сла́гът им кръва́йчитъ/ къмф'е́ти/ куври́гъниъъ/ ра́зну n'е́ч'ъну/ о́рий/ а на по-сво́йти/ н'а́куй ру́бличкъ// Стопа́нкъть сла́zа на ма́съть лук/ ч'е́сън/ о́рий/ м'ет/ труш'е́йе/ гро́зди ису́ш'ену/ мируд 'е́йе// На трап 'е́зътъ/ тр 'а́бъ дъ и́ма по́сну йе́дини/нич'е́т'ен брой// Прикад’а́въни/ най-въззраснийа прикад'а́ва с тъм'а́н/ ръсчу́пва о́бр'еднийа л’ап/ и да́ва на с'е́ки пу ино́ пърч'é// П'е́рвото пърч 'é/ зъ свита́ Бугуро́йцъ// О́коло суфра́тъ по-ра́ну дъ с'е съб'еръ́m/ ут тва зави́си ра́ното узр 'а́ван'е на жи́тоту// Изб'а́гвът дъ ста́вът/ зъко́ту кло́пкити жъ ста́вът ут ииа́ть/ и н'а́мъ дъ измъттът пи́л'ъниъ// Хъз'а́инъ мо́ж'е дъ ста́ва/ но mp'а́бъ дъ о́ди прив 'е́дън/ дъ съ приви́й жи́туту/ ут зъ'рнуту// Хо́d ’ъm пу къитити със дзвиздъ'// Хъз 'а́инъ завъ'рзва на дзвиздъттъ пу инъ къ́рпъ/ и́ли къси́нкъ/ гушта́въ ги/ да́ва им кръва́йчи/ ру́бль (Чш)// Ут шести на с'едми вич'арть/са оди на служба на ч'ерквата// Вич'арть сич'ката с'ем'йа за столом/ да са найадът// Йаст'ата на стуло тр'аба да бъдат посни бл'уда// Тр'аба да има свар'ена кучи/ можи в'ешти ушау/ боб/ посна сармъ/ вар'ени картоул'а/ салат уд з'ели (Кр)//].

Къщата се подрежда и се готвят специални обредни храни, като обредната организация на храната е постна. Това са варени постни ястия от 
боб, леща, сарми (гушки, галубич), тиквеник, зелник, варено жито с чукани орехи, стафиди, мед и мак (куm'a), ошав от сушени сливи, круши, кайсии, ябълки и други сушени плодове. Слагат се на масата и различни туршии (закупорки, закрутки, кис'алу), мед, чесън, лук. Смята се, че ястията трябва да са 12 на брой. Пекат се и обредни хлябове за трапезата - богувички, украсени с кръст и четири топчета отгоре (прусурки), а за коледарите - краваи от сдобну тисто кту на паска (козунак), украсени с различни орнаменти.

В повечето бесарабски села през деня ходят да пеят малки коледарчета, кулидари кулидарник (Чш) момченца от 5 до 12 г., облечени в нови дрехи, с преметнати турбички (3), дисаги (Чш) за подаръци, в ръцете носят зв'езда (Куб, НТ), звизда (Кул), звиздъ// cm 'ава < рум. steauă (Чш) дървен крьг или звезда по средата с икона на Света Богородица, горе прикрепено дзвънче, на дръжката стопанките вързват пишкир или кърnа, обикалят по домовете и викат „Славит'е ли Млада Бога?“. Като влязат в двора, почват да пеят: „Стани, станинине, стани господине, утурете, утклучете, чи ви идим добри гости, добри гости коледари. Дай един шай (паричка) и един кравай (НТ)““ (Стрезева/Strezeva 2000: 468); // На звизда ходат да п'айат по-гул'ами д'аца / тийа фл'ават фо двору и викат / „, Чи Иван'е (Васил'е) / шна пуснити да п'айам на звизда?." / хаз'айану ги пита / „Ми/ чий сви? Ай/ фл'авайти!'“/ Дицата дражът ф правата ръка звиздата / ми фо л'авата звънч'ету и стават насришту кун'та / пузвъни в звънч'ету и закача да п'ай / кту исп'ай тожи звъни със звънч'ету// Хаз'айката ги пуфал'а / и им дад'е имиш и н'акуй рубла// И ткай и'ала нош / дурде ни съмни (Кул)//]. Влизат в къщата, застават срещу иконата и пеят песни основно с християнски мотиви. След като изпълнят рождественския репертоар, стопаните ги даряват с канф'ети (бонбони), пр'аники (бисквити), кравайчита и дребни пари. В село Заря (Камчик) момченца и момиченца, водени от бащи и по-големи братя, през деня и привечер ходят по домовете на Сла̀ва тилибо̀zа (Славите ли Бога?) и пеят песен:

Рождество твое, Христе Боже наш.

Восия миром и свет разума.

С неба звездою служашихся

и звездою учахося.

И тебе клонится солнце правды,

И тебе видится с высоты востока.

Господи, слава тебе.

Амин.

Когато завършат да пеят, момченцата казват: „Шику, лаку, дай петаку! “. Стопанинът им дава пари и сладости. Песента „Рождество твое, Христе Боже наш... “ е своеобразна редакция на редактирания старобългарски език. Това е тип църковно пеене, характерно за украинските източноправославни богомолци - да пеят едновременно с духовното лице в речитатив или 
просто скандиране. Бесарабските българи са го заели от източнославянската православна традиция, т.е. това е своеобразна интерференция.

Преди вечерята най-възрастният в семейството прикад'ава с там'ан трапезата и ч'ете м'олитвата: [//Кту мръкни сичката сим'а с'ада за стулом да идът // Хаз'айану (или хаз'айката) турга на лупатката ж'ар и тим'ан / и туга кади сичкити къшти / дубитъку най на пусл'едък кади столу и сичкити / койту сидът за стулом три път'а / а пък на трета́ път' л'ефичку ги чука пу главата да бъдат здрави // Се́етни то ж'ар гу тургат пут столу // Сичкити са кръстат и с'адат да идът // Най главн'а в сим'ата зима бугувичката / на куйату има питчица с красл'енци // Питчицата а ч'упат и а насипуват със сол и житу / и утрината а дават на дубитъку // Пък бугувичката а ч'упат наопаци със главата и а нарицат на зърну / куйату стърна пойчи са ш'ч' упи / значи там ши има пойчи уруж'ай (наприм'ер / правата зимница / л'авата пашой) // Се́тни та сайчица са ч'упи на парченца и са ид'е // На столу има житу / кампот / н'аква варе́на мандж'а и сичку тра̀ба да бъди посну // Гату сичкити са найдът / са дига столу и ч'акат звиздити (Кул) //]. Цяла нощ пред иконата гори огън в кандилото. В миналото вече е останало целонощното горене на бъд-

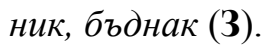

За Коледа се коли прасе, разговява се със свинско. На коледната трапеза задължително има n'екану прас'енци. На този празник нищо не се работи. Започва се с обичая коледуване. В него участват момци и млади мъже-коледари (НT), коладници (Г, 3), коледарници (Чш), които започват подготовката още месец преди празника. Те се разделят на дружини, чети. След това, в дружините се избира предводител - ку́да (3), станеник (Г, $\mathbf{3}$, Чш), цар (Куб), поп (НТ). За водач се избира този, който знае най-добре коледните песни, с най-хубав глас и може най-бързо да нарича богословката.

Коледуват само мъже ергени, годеници и по-млади, скоро женени мъже. Всички носят едно общо име, което в отделните български говори в метрополията е в различни форми - коледари, коладници, коледаре, коледнищи и пр. След образуването на дружините бъдещите коледари започват да си избират водач.

Месец преди празника започват да се организират в групи коेлуви (Kр), дружини (3), куди (Чш), момци и младоженци, които искат да бъдат коладници// коледнищи (3), коледари (Г, Вин, НТ), коледарнищи (Чш), куди (Г, Вин, НТ). Групите се състоят от 4 до 12 души.

Сформират се толкова дружини, колкото са улиците (махалите) в селото. Но тъй като момците и мъжете са много, а всяка дружина се състои само от определен брой хора, се налага те да бъдат избирани. Правилата за това са много строги и както казват в село Заря (Камчик): „Конкурса б'еши гул'ам“. Подбора извършват няколко от най-уважаваните възрастни мъже, които на млади години неведнъж са били коледари. Обикновено се избират ергени, които вече са сгодени. Но едно от основните условия е те да могат да пеят добре, затова в дружините се включват и несгодени мом- 
ци с певчески способности, красиви, снажни и куражливи. По същите причини се включват и женени млади мъже, които преди това много пъти са коледували. Всеки от сгодените момци се стреми да бъде в дружината, която ще ходи в дома на годеницата му. Това внася известни трудности при разпределянето на улиците между дружините, още повече че им е забранено да отидат на друга улица. Забраната се нарушава само когато предварително не е постигнато нужното разпределение. Тогава се позволява на една дружина да отиде на друга улица, но тя има право да посети само къщата на годеницата на своя коледар. След това всяка дружина си избира водач - куда (3), поп (НТ), станеник (Г, Зд, Вин, Чш), стареи, куда (3). Названието куда в значение 'водач' е зафиксирано само в село Заря (Камчик). В БЕР думата куда е в значение 'коледарска чета' (Варненско; Козичино, Поморийско; Одринско), 'група хора' (Дивдядово, Шуменско; Сев. Добруджа), 'дружина' (Родопите). - Произв.: ку́даджия 'коледар, който изрича благословията' (Козичино, Поморийско; Сев. Добруджа); куда̀баши 'водач на коледарска чета', ку́дабашия също (Толбухинско) (-башия от тур. başi, изафетна форма от baş 'глава'; предводител) (БEP/BER III 1986).

Водачът си има помощник (Зд), даскал (НТ). Останалите коледари в коледарските дружини котките и магарето имат функцията да събират и носят подаръците. В някои бесарабски български села е познато водене на Коза (3, Куб) // Капра < рум. Сàpră ‘коза, седалка на файтонджия’ (В).

Водач става този, който има най-хубав глас, най-добре знае коледните песни и най-бързо изрича богослоффката, богуславката, благословката 'коледната благословия', която е сравнително кратка по обем и се явява като епилог на цикъла песни за всяка къща.

Коледарите са в традиционно празнично облекло. Връхните дрехи за цялата дружина трябва да са еднакви - черни шапки и шуби, черни вълнени панталони, чизми (3, Куб). На главата си имат астраганени гугли 'калпаци', украсени с нанизи от златни и сребърни монети медальончета, към които се прибавят китка и друга украса. От полунощ до сутринта те обикалят домовете. По пътя, пред вратата и в къщата пеят специални обредни песни, различни по мотиви, според мястото на изпълнение и лицето, за което се пеят. Коледарите имат богат репертоар от песни, тъй като във всеки дом задължително трябва да изпеят подходяща песен за всеки от семейството. Различни песни се пеят за стопанина, за момък, за девойка, за дете. Най-общо те съдържат обредно пожелание за щастие в семейството и добив в стопанството. Всяка дружина си има по 8-10 души помощници, които също се избират, но в техните групи има и по един-двама възрастни мъже. Най-възрастният и най-почитан се определя за варда̀ч. Той отговаря за дисциплината в дружината, за подаръците, които коледарите получават, и най-вече следи да не мине дружината по друга улица (махала (3), майль, мъйль (Чш), защото може дружините да се срещнат, а ако това стане, може да се стига до лабу́m 'бой' между тях. 
Стопаните са будни, стопанството, в това число и кучетата, са заторини, закл'учини, (запрени). Коледарите започват да пеят тъй наречената песен на вратата:

Ку си сън'ан буд'ан бади -

Стан'ай, стан'ай, нин 'ай, господин'e!

Ку си пийан тр'ез'ан бади

Чи ти идат добри гости

Добри гости коладници

Чи шти п'ейат личан п'ес'ан.

Тази песен има различни варианти, но навсякъде се пази обрьщението: Стан 'ай, стан 'ай, нин'ай, господин'e! (Георгиева/Georgieva 2005: 39-42).

След това всички влизат в къщата и четирима коледари се допускат до гол'амата къшта 'най-голямата и представителна стая, която е предназначена за гости', където сядат на дългия стол. Останалите членове на дружината с вардача остават в коридора и оттам през отворената врата наблюдават ставащото. Стопаниньт и стопанката с цялата си челяд сядат срещу четиримата коледари. Поръчката за песните дава стопанинът. И колкото по-многобройно е семейството, толкова по-трудно е на коледарите. Песните за прослава на домакина заемат централно място в коледния репертоар. За да поласкаят гостолюбието на стопанина, коледарите го издигат до най-високия крьг, до самия Бог и светците (напр. „Проч'ул ми са й изар Константин").

Певците не се ограничават само с добра вест или похвала за домакина. Останалите членове на семейството също трябва да бъдат зачетени по обичая. В село Заря (Камчик) например се пее на ерген „Сношти минах приз гурица“, на мома „Пофаляла са Станяна майка“, на момче „,Малку мунче кон сидлае“, на момиче „Белила ѝ малка мома“, на дете „Данюва майка, Даню люляйши“. Записани са още следните коледни песни: „Свити ми Петар и Димитар “, „Субрали са светом светщи “, „, Свети Георги кон сидлаи “, „Рождество Христово, ангел прилител“ “ и др.

За празника стопанката приготвя вит, превит кравай за коладнищите, а стопанинът - пари и гърне, бъклица с „, червено руйно вино “. След като всеки бъде поздравен със съответната песен, стопанката подава коледарския кравай на Кудата (3). Като епилог на цикъла песни за всяка къща задължително се явява речитативната благословия. Kудата (3) повдига кравая високо над главата си и изрича коледарската благословия, наричана богосло̀ката - благословията за здраве, за сполука, за плодородие и т.н. Този момент е изпитание за Kyдата, тъй като той трябва да покаже умението колко бързо и ясно може да изрече благословията. В този момент не само домакините, но и помощниците, които наблюдават през отворената врата, дават оценка на Kудата. Тя е от голямо значение, защото в продължение на месец след Коледа обект на коментари в селото са уменията на всички куди и кой как се е представил. 
Дареният кравай го нанизват на дълъг прът, който е неизменен атрибут на дружината. Понякога помощниците носят три-четири дълги прьта, на които можело да се нанижат по над десет вити кравая. Когато прьтовете се напълнят, оставят краваите в къщите, където има мома за женене.

Когато свърши коледуването, дружината се сбогува със стопаните, като им пожелава: На здрав'и т'и добър стан 'ан'ин! Колку в н'еб'е др'ебн'и зв'езд'и, толкус здрав'и в таз'и къща! Дружината се сбогува със стопаните и излиза от къщата с песен:

Н'е йа иे навънка (2),

Госпут нафътр'а (2).

Те ройне ле, дойне ле, брайне ле, колко в небе дремни звезди,

толкоз здраве в тази къща.

Излязат ли коледарите от къщата, счита се, че Бъдни вечер е минал, че са дошли мръсните дни. През тези дни ходят маскирани обредни групи старии, джамали, бабугери и др. Тези групи ходят до Водици. Старците носят дървени топузи, дървени пушки, имат си „булка“ с дете - мъж, облечен в невестински дрехи.

В село Ореховка (Пандаклий) това вече не си го спомнят дори и найвъзрастните хора: [//У нашту с'елу ни од'ат да коладват/ то са загубилу уж'е/ дииата од'ат на джамали нушт'а сришту новата гудина и на другийа д'ен $(\mathbf{O p}) / /]$. Знае се само, че в Джамала участват шест-седем млади момчета, 14-18-годишни. Момчетата правят една дървена конструкция, наричат я тарга, която носят от двор в двор. Таргата е централен персонаж. На нея слагат козя кожа. Започват да ходят по къщите около дванайсет часа през нощта. Момчетата влизат в двора, пеят песни, танцуват и бият таргата. Групата няма водач, един от тях носи таргата, другите свирят на музикални инструменти. След като обиколят няколко двоpa, друго момче взема таргата. Участниците се обличат в стари дрехи, боядисват лицата си, поставят си брада и мустаци от вълна. Стопаните им дават пари и дарове, често това са кравайчята и канфети. До наше време са достигнали само няколко елемента от този обичай. Днес децата вече не правят тарга, а само ходят по дворовете и пеят песни, за което получават от стопаните дарове: [// ...ca cбират ym u'ec dy dec'am ran'ama ny чит'арнајси, и'аснајси гудини. Тиј прајат ут дэски ина тарга, на н'еја забиват ина козишка кожа и ут дванајси часа нач'еват да од'ат пу дуровити. Таргата га нос'ат пу идин, ама са мин'ават, закоту т'а т'еж-

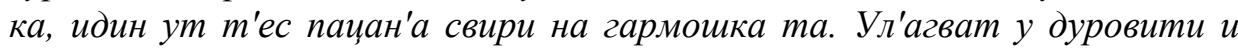
нач'еват да п'ејат и да бијат таз'а тарга. Ут дор на дор на тиз'е младити пацан'а им дават пари, канф'ети, пр'аники, кравајчата. Угату закончат да од'ат, пацан'ата са сбират у идинија ут m'aу и утм'ечават новата гудина, дил'ет н'егу, куйету гу сбраја (Ор)// Нушт'а йерг'ен'ат'а /кол'едарит'а/ са збират и од'ат на ката къшта да пуит на траки/ 
вътри раитат'а// Този прои'ес са дума /да одим на траки// Напр'ад туй/ тий са збират у н'акуй стар д’адучку/ той ги учи ак'е тр'аба да пуит/и акви слува// Тий имат пу инъ трака вътр'а раџат'а/ од'ат ду ката къшта// Ората им дават пишкир'а/ кравайч'уута/ рубл'а/ и ги ч'ерп'ат сас пу инъ ч'аш'а вину// Тий пуит таквъзака п'асин:Сабрали са сабур момщи/ Станини ни н'е, госпудин'е/ Сабур момии/ коладнище/ Да си утод’ат на равни дори/ На равни дори/ на чимшир порти// Ставай/ ставай/ стар станиник/Пийан ли си/ тавр'аз бади/ Сън'ан ли си/ буд’ан бади/ Ч/е ти дошли добри гости/ Добри гости/кол'едари (Кр)//].

И така до сутринта: [//На втора̀ дѐн ората си раздават краваити. Пудар оба̀d ода̀m на уро. На трета̀ д ен пуказват краваити ги носа̀m на м егдана̀.Маж 'ети на каруци карат пу мегдана̀ и кра̀скат: „тос кравай на еди куа̀ мума, тос на другата“. Сичкити гл 'едат чий кравай най-убав (B)// Удзурантъ пак има служба на ч'ерквата// Ората ода̀m да са мол'ат на Госпуда̀// На този д'ен/ са пуит таквизаки п'асни: Служба служил, кулад/ел/е/ Св'ети Иван/ кулад 'ел'е/ Слуга му б'еш'е' кулад'ел'е/ Св 'ети Г'еорги/кулад 'ел'е/ Утгувар'а/ кулад'ел'е/ Св'ети Иван/кулад'ел'е/ Многу ми си/ кулад'ел'е// Послугувам/ кулад'ел'е/ Слугувай ми/ кулад'ел'е/ Омти малку/ кулад'ел'е/ Дурд'ет дойдат/кулад'ел'е/ Двата д'ена/ кулад'ел'е/ Йердануу д'ен/ кулад'ел'е/Ивануу д'ен/ кулад'ел'е/ Дай на здрав'е/ кулад'ел'е/ Св 'ети Иван/кулад'ел'е/ Св'ети Г'ерги/ кулад'ел'е (Кр)// На друг'а д'ен са разгув'ават (уж'е са иде блажну) / ходат на гости // На тр'ет'а д'ен на Кол'да са ходи на гроб'ишта (Кул) //

До обяд коледарите си почиват, а следобед вардачът им приготвя шейна, в която впряга най-буйните коне. Накривил калпака си, той събира с шейната всички коледари и с песни и веселба си прибират краваите, които през нощта са оставили в домовете на момите. Трите дни на този празник нищо не се работи.

Коледарската благословия, в метрополията означавана още като молитва, благословка, богосло̀кка, богуславка, слава, блажанка, блаженица и др., се явява словесна съставка на обичаите и обредите по Коледа. Тя представлява речитатив, произнасян от член на коледарската чета след получаването на коледния кравай. Този текст трябва да се възприема като заклинателен, като словесна магия, осигуряваща благоденствие и щастие на дарителите (Колев/Kolev 1996: 361). По своята структура всяко магическо действие се състои от слово и движение. Магията на словото е известна като вербална магия. Тя е отрицателна (клетва, анатема) и положителна (благословия или благопожелание). Основана на вярата в добрите магически качества на словото, тя цели да предопредели и осигури здраве и дълголетие, богата реколта и добър приплод на домашните животни, имотност и щастлив съпружески живот (БМ/ВМ 1994: 29). Според А. Калоянов: „Благословията не се е разсипала през вековете, защото е била пазена като най-голямо богатство от самите коледари - наградата за всички изпитания, реални и въображаеми, е полученото право да благославят“ (Калоянов/Kaloyanov 1986: 115). 
Като пример ще анализирам „Богословката“, която съм записала през 1995 г. (Георгиева/Georgieva 2005: 42). Този текст трябва да се възприема като заклинателен текст, като словесна магия, осигуряваща благоденствие и щастие на дарителите. Коледарската благословия започва с приканването на коледарската дружина от благословника да прославят Бога или определени светци:

[//Йас да рича по св'ети Никола/ ни дружини благославим// Амин//]

Следва описание на коледарското пьтуване, което е свързано с дълъг път, с преминаване на препятствия и понасяне на несгоди:

[//Сношти/ полуношти/ што сми път'а пътували/ кал'а трава путъпкали/ черни м'етки пурусили// Йас та рича пуслид’а Никола дружсина// Амин//]

Регистрират се следните словесни формули: прослава на бога, описание на дългия път на коледарите и препятствията, които те трябва да преодолеят, посрещането на коледарската чета от домакина и др. Провикването след всяко отделно наричане с евангелското амин говори за сериозното обредно осмисляне на първоначалния монолог.

[//Това наша стар'а стариник, кому било най-милу и драгу, дадуха добри чисти синуви и дубри чисти дъшт'ери. Синуви са ж'енат, къшти събират. Дъшт'ери са ж'енат, къшти разнасат. Той са жалну нажали, гн'евну, чи си грамна златна пат'ерища, чи си погна синуви и дъшт'ери. Прис пусти чузди т'ел'еги. Той ни стигна синуви и дъшт'ери. Той най стигна свитога Иван, на път'а крайну път'а, д’ету куринската мугила, д'ету гул'ама д'алба дил'еши. Кум брату паничка, кум брату лажичка. На това наша стариник са падна най-малката лажичка, старовука паничка, д'ету бире кил'ие, кил'че и пулвина. Той слага га ут ръие на ръие, чи га тури в златна л'улка. Лула л'ул'аше, п'ес'ан му п'ейше: „Расти, расти синко, гул'ам да пурасниш. Да тръгниш пудар вакли оेвии, да дувиш б'алу мл' 'аку, да сириш пр'асну сирини, да ср'ашкаш пътници и друмишта. Да изплашташ майчини и баштини гр 'ахуви. Йас да рича по св'ети Никола, ни дружсина благословим. Амин. Раслу, пураслу тва чеду, то ни тръгналу пудър вакли овии, да дуви б'алу мл'аку, да сири пр'асну сирини, да изплашта майчини и баштини гр'ахуви. То най тръгналу пу далбоки доли, пудар чарнооки моми кату майка му и башта му на млади години. Йас да рича по св'ети Никола, ни дружина благословим. Амин“"/]

Коледарската благословия завьршва с неразгърнато благопожелание, което е типично за коледарските песни:

[//Тоз кравай в'uт, пре́ви́т, пре́д Бога пе́чен, на нас наре́чен. Колкото са зръниа у не́го - мла́ти́, премла́тú, ва́ти́, прева́ти́, толкус здрави́ и чест в тази́ къшта//]

Следва приканването на дружината още веднъж да прослави Господ, осигуряващ благоденствието в посетения дом:

[//Да риччем, дружина: ”Ами́н!//]

Записаният вариант на коледарската благословия се отличава с липса на цялостна логическа и формална структура, което се дължи на забравя- 
не, изпускане или променяне на първоначалния обреден текст, или импровизиране на благословника, което според Н. Колев „до известна степен затруднява нейния анализ, но в същото време говори за творческия гений на българина“" (Колев/Kolev 1996: 362).

Фонетико-стилистичната парадигма е с ограничени изразни възможности. Звуковете на речта, тяхната съчетаемост и съзвучие са предопределени в най-голяма степен от повторяемостта им, която усилва и тяхната изразителност.

В текста се забелязва склонност към йотуване на началните гласни, което отсъства в съвременния диалект на зарянците, напр.: йас, йабалка... Ударението, чрез което се изграждат ритмическите структури в обредния текст, усилва тяхната емоционалност и изразителност.

Морфологично-стилистичната парадигма се изгражда от варианти на една и съща словоформа, като част от тях имат стилистична маркираност, свързана с народния поетически език или с рядко, диалектно, остаряло използване на тази дума, а други са неутрални и общоупотребими, напр. съществителното дол е представено със словоформата доли (далбоки доли - диал. ост., стил. марк.).

В областта на морфологията са запазени най-много старинни особености в езика на богословката. Запазването на старинни форми тук се дължи на това, че думите по начало трябва да се помнят наизуст и да се възпроизвеждат без отклонения. Това дава възможност те да достигнат до днешно време, предавани от поколение на поколение. Една от особеностите на анализирания текст е употребата на старинни падежни форми при имената, напр. в изрази като кум брату паничка/ кум брату лажичка// стигна свитога Иван/и др., несвойствени за съвременния говорим език.

При едносрични и сложни съществителни имена има колебания в граматическата категория род, дължащи се на диалектни влияния: личан n'ec'aн (диал. песн'a). Особено важна старинна особеност в текста е твърде честата употреба на съществителни или прилагателни имена без член: Синуви са ж'енат/ къшти събират// Дъшт'ери са ж'енат/ къшти разнасат//;/чи си грамна златна пат 'ерица/ чи си погна синуви и дъшт'ери//; тръгналу пу далбоки доли/ пудар чарнооки моми/ и др.

Синтаксисът на обредния текст се отличава със своята простота. Тук се среща безсъюзно свързване на прости изречения, употребени самостойно или в рамките на сложно съчинено изречение. При сложните съставни изречения се срещат всички типове подчинени изречения, често с натрупване на еднородни подчинени.

Коледуването като ергенски ритуал на прехода запазва една строга регламентация на ред, последователност и откриване на пространства за житейска реализация, свързана с бъдещия семеен живот и социално утвърждаване.

Бесарабските българи, които вече 8-9 поколения живеят сред друго етническо и езиково обкръжение, са запазили същностните черти на българ92 
ската етнокултура. Постепенното изменение на обичаите и обредите, свързани с Коледа, не довежда до промяна на обредния текст. Това се дължи преди всичко на настъпилата промяна в живота и бита на населението, която поражда необходимост от преосмисляне и връщане към богатството на българските обичаи и традиции, чрез които нашите прадеди ни предават своята жизнена сила, духовна мъдрост и национално самосъзнание.

\section{ПРИЛОЖЕНИЕ}

Списък на селата, съкратеното им название и тип говор

В курсив е дадено старото название на селото, а в получер шрифт - съкратеното означаване, което се използва в текста.

Василевка (Вайсал) - В - Одеска област, Болградски р-н - смесен балкански и тракийски говор

Виноградовка (Чумлекьой) - Вч - Одеска област, Тарутински р-н - балкански говор

Главани - Г - Одеска област, Арцизки р-н - балкански говор

Городне (Чийшия) - Чш - Одеска област, Болградски р-н - чийшийски говор

Делжилери - Дл - Одеска област, Татарбунарски р-н - балкански говор

Евгеновка (Аpca) - E - Одеска област, Тарутински р-н - балкански говор

Задунаевка - Зд - Одеска област, Арцизки р-н - балкански говор

Заря (Камчик) - 3 - Одеска област, Саратски р-н - смесен балкански и тракийски говор

Каменка (Ташбунар) - Кам - Одеска област, Измаилски р-н - чийшиски говор

Кирнички (Фънтъна- Дзинилор) - Кир - Одеска област, Измаилски р-н балкански говор

Криничне (Чушмелий) - Кр - Одеска област, Измаилски р-н - чушмелийски говор

Кулевча - Кул - Одеска област, Саратски р-н - тракийски говор

Нови Трояни - НТ - Одеска област, Болградски р-н - тракийски говор

Ореховка (Пандаклия) - Ор - Одеска област, Болградски р-н - балкански говор

Ровное (Купоран) - $\mathbf{P}$ - Одеска област, Тарутински р-н - балкански говор

Суворово (Шикирли-Китай) - C - Одеска област, Измаилски р-н - тракийски говор

Кубей - Куб - Одеска област, Болградски р-н - смесен чушмелийски и балкански говор

Терновка - T - Николаевска област - тракийски говор

\section{ОСНОВНИ ИНФОРМАТОРИ}

Бааджи Михаил Михайлович - 73 год., българин, образование 8 кл., Куб. Бурукова Степанида Ивановна - 80 год., българка, образование 5 кл., Чш. Граматик Степанида Николаевна - 60 год., българка, образование висше, Кул. 
Дерменжи Елена Николаевна - 80 год., българка, образование 5 кл., Кам. Димо Надежда Алексеевна - 78 год., българка, образование 7 кл., Т. Желев Владимир Степанович - 75 год., българин, образование 8 кл., 3. Кисеолар Ивана Василевна - 80 год., българка, образование 3 кл., Р. Кустурова Елена Николаевна - 56 год., българка, образование средно, Вч. Митанов Димитър Степанович - 72 год., българин, образование средно, Кр. Настрадин Мария Родионовна - 68 год., българка, образование средно, Г. Николаева Валентина Василевна - 54 год., българка, образование висше, НТ Станкова Прасковия Ивановна - 72 год., българка, образование 8 кл., Ор. Туфекчи Акулина Васильевна - 70 год., българка, образование 6 кл., В.

\section{ЛИТЕРАТУРА}

Барболова 1999: Барболова, 3. Българският говор в с. Червоноармейское (Кубей), Бесарабия. Одеса, Астропринт.

Барболова 2013: Барболова, 3. Българският говор в николаевската Терновка (Украйна). Одеса, Симекс-принт.

Барболова, Колесник 1998: Барболова 3, Колесник В. Говорът на българите в с. Кирнички, Бесарабия. Одеса, Астропринт.

БЕР III 1986: Български етимологичен речник. Том 3. София, Издателство на БАН.

БМ 1994: Българска митология. Енциклопедичен речник. София, Издателска група 7M + Логис.

Георгиева 2005: Георгиева, С. Обичаят „коледуване“ и обредният текст „коледарска благословия“" в село Заря, Одеска област. - Българска Бесарабия: Проблеми на език и литература, история и изкуство на българите в Украйна и Молдова. Вип. ІІІ. Болград, с. 39-42.

Георгиева 2011: Георгиева, С. К вопросу идентификации диалектных особенностей бессарабских болгарских говоров. - Науковий вісник ПНПУ ім. K. Д. Ушинського. Лінгвістичні науки. Збірник наукових праџь. Одеса, Астропринт, № 13, с. 91-96.

Георгиева 2013: Георгієва, С. Болгарські діалекти в Україні: еволюція досліджень. - В: Компаративне дослідження слов'янських мов і літератур. Пам'яті академіка Леоніда Булаховського. Збірник наукових пращь. Київ: Освіта України, Вип. 23, с. 29-36.

Георгиева 2015: Георгіева, С. Българският преселнически говор в село Заря (Камчик), Украйна. Идиолекти. Речник. Одеса, Астропринт.

Георгиева 2017: Георгиева, $C$. Народният календар на бесарабския българин: езиково-културно интерпретиране. Речник. - Проглас, кн. 1, Велико Търново, Университетско издателство „Св. Св. Кирил и Методий“, с. 56-69.

Георгиева, Колесник 2016: Георгієва, С., В. Колесник, Болгарські говірки Півдня України. Хрестоматія. Тексти. Ізмаїл: „ІРБІС“.

Державин 1914: Державин, Н. С. Болгарскія колоніи в Россіи (Таврическая, Херсонская и Бессарабская губерніи). София: Издателство „Мартилен“, с. 171-173.

Калоянов 1986: Калоянов, А. Добър юнак с добра коня. Варна, Изд. „Г. Бакалов“, с. 113-115. 
Колев 1996: Колев, Н. Коледарски благословии от Ямболско. - В: Българите в Северното Причерноморие. Т. 5. Велико Търново, Университетско издателство „Св. св. Кирил и Методий““, с. 361-368.

Колесник 2008: Колесник, В. Говорът на българите в с. Криничне (Чушмелий), Бесарабия. Речник. Одесса, „Друк“.

КПОБ 2000: Календарни празници и обичаи на българите. Енциклопедия. София, Издателство на БАН.

Легурска, Китанова 2008: Легурска П., М. Китанова. Тематичен речник на термините на народния календар. София, Академично издателство „Проф. Марин Дринов“".

Стрезева 2000: Стрезева, Н. Коледни обичаи и коледарски благословии от Придунавска Бесарабия като извор за българската народна култура. - В: Българите в Северното Причерноморие. Т. 7. Велико Търново, Университетско издателство „Св. св. Кирил и Методий“, с. 467-472.

\section{REFERENCES}

Barbolova 1999: Barbolova, Z. Balgarskiyat govor v s. Chervonoarmeyskoe (Kubey), Besarabia [The Bulgarian Dialect in the Village of Chervonoarmeyskoe (Kubey), Bessarabia]. Odesa, Astroprint.

Barbolova 2013: Barbolova, Z. Balgarskiyat govor v nikolaevskata Ternovka (Ukrayna) [The Bulgarian Dialect in Nikolaevska Ternovka (Ukraine)]. Odesa, Simeks-print.

Barbolova, Kolesnik 1998: Barbolova, Z., V. Kolesnik. Govorat na balgarite v s. Kirnichki, Besarabia [The Dialect of the Bulgarians in the Village of Kirnici, Bessarabia]. Odesa, Astroprint.

BER III 1986: Balgarski etimologichen rechnik [Bulgarian Etymological Dictionary]. Vol. 3. Sofia, Izdatelstvo na BAN.

BM 1994: Balgarska mitologiya [Bulgarian Mythology]. Entsiklopedichen rechnik [An Encyclopedic Dictionary]. Sofia, Izdatelska grupa 7M + Logis.

Georgieva 2005: Georgieva, S. Obichayat „koleduvane“ i obredniyat tekst „koledarska blagosloviya“" v selo Zarya, Odeska oblast [The Custom of Koleduvane and the Ritual Text of the Christmas Blessing in the Village of Zarya, Odessa Region]. - Balgarska Besarabia: Problemi na ezik $i$ literatura, istoriya $i$ izkustvo na balgarite v Ukrayna i Moldova [Bulgarian Bessarabia: Issues in Language, Literature, History and Art of the Bulgarians in Ukraine and Moldova]. Vip. III. Bolgrad, 39-42.

Georgieva 2011: Georgieva, S. K voprosu identifikatsii dialektnykh osobennostei bessarabskikh bolgarskikh govorov [On the Identification of Dialect Features of Bessarabian Bulgarian Dialects]. - Naukovii visnik PNPU im. K.D. Ushins'kogo. Lingvistichni nauki. Zbirnik naukovikh prats'. Odesa, Astroprint, 2011, № 13, 91-96.

Georgieva 2013: Georgieva, S. Bolgars'ki dialekti v Ukraïni: evolyutsiia doslidzhen [Bulgarian Dialects in Ukraine: Development of Research]. - Komparativne doslidzhennia slov'yansykikh mov i literatur. Pam'iyati akademika Leonida Bulakhovs'kogo. Zbirnik naukovikh prats'. [A Comparative Study of Slavic 
Languages and Literatures. Collection of Scientific Works]. Kiïv, Osvita Ukraïni, 2013, Vip. 23, 29-36.

Georgieva 2015: Georgieva, S. Balgarskiyat preselnicheski govor v selo Zarya (Kamchik), Ukrayna. Idiolekti. Rechnik [The Bulgarian Emigrants' Dialect in the Village of Zarya (Kamchik), Ukraine. Idiolects. A Dictionary]. Odesa, Astroprint.

Georgieva, Kolesnik 2016: Georgieva, S., Kolesnik, V. Bolgars'ki govirki Pivdnia Ukraïni. Hrestomatiia. Teksti [Bulgarian Dialects in the South of Ukraine. A Reader. Texts]. Izmaïl:"IRBIS".

Georgieva 2017: Georgieva, S. Narodniyat kalendar na besarabskiya balgarin: ezikovo-kulturno interpretirane. Rechnik [The Folk Calendar of Bessarabian Bulgarians: Linguistic and Cultural Interpretation. A Dictionary]. - Proglas, kn. 1, 2017. Veliko Tarnovo, Universitetsko izdatelstvo „Sv. Sv. Kiril i Metodiy“, 5669.

Derzhavin 1914: Derzhavin, N. S. Bolgarskiia kolonii v Rossii (Tavricheskaia, Hersonskaia i Bessarabskaia gubernii) [Bulgarian Colonies in Russia (Tavricheskaya, Kherson and Bessarabian Provinces)]. Sofia:Izdatelstvo „Martilen“, 171173.

Kaloyanov 1986: Kaloyanov, A. Dobar yunak s dobra konya. Varna, Izd. „G. Bakalov", 113-115.

Kolev 1996: Kolev N. Koledarski blagoslovii ot Yambolsko [Christmas Blessings from Yambol Region. - In: Balgarite v Severnoto Prichernomorie [The Bulgarians in the Northern Black Sea Coast Region]. Vol. 5. Veliko Tarnovo, Universitetsko izdatelstvo "Sv. Sv. Kiril i Metodiy", 361-368.

Kolesnik 2008: Kolesnik, V. Govorat na balgarite v s. Krinichne (Chushmeliy), Besarabia. Rechnik [The Dialect of the Bulgarians in the Village of Krinichne (Chushmelii), Bessarabia. A Dictionary]. Odessa, „Druk“.

KPOB 2000: Kalendarni praznitsi i obichai na balgarite. Entsiklopediya [Calendar Holidays and Customs of Bulgarians. An Encyclopedia]. Sofia, Izdatelstvo na BAN.

Legurska, Kitanova 2008: Legurska, P., M. Kitanova. Tematichen rechnik na terminite na narodnia calendar [Thematic Dictionary of the Terms in the Folk Calendar]. Sofia, Akademichno izdatelstvo „Prof. Marin Drinov“.

Strezeva 2000: Strezeva, N. Koledni obichai i koledarski blagoslovii ot Pridunavska Besarabia kato izvor za balgarskata narodna kultura [Christmas Customs and Christmas Blessings from Pridunavska Bessarabia as a Source for Studying Bulgarian Folk Culture]. - In: Balgarite v Severnoto Prichernomorie [The Bulgarians in the Northern Black Sea Coast Region]. Vol. 7. Veliko Tarnovo, Universitetsko izdatelstvo "Sv. Sv. Kiril i Metodiy", 467-472.

\section{РЕЗЮМЕ}

Народната терминология е израз на националната специфика на културите и в този смисъл изучаването ѝ е перспективно в рамките на формиращите се тенденции за европейско мислене от началото на XXI в. В статията се проучват коледните обичаи и обреди в етнолингвистичен аспект, анализира се коледарска благосло- 
вия, която е словесна съставка на обичаите и обредите по Коледа, с описание на лингвостилистичните особености на художествен обреден текст. Ко̀лда (А, Вч), Ко̀л’да (3, Кул), Ко̀л'еда (Кам), Ко̀лада (Дл, А, Кр, Куб), Ко̀л'ада (Куб), Ко̀лида $(\mathrm{C})$ е най-големият и най-богат в обредно отношение зимен религиозен празнично-обреден комплекс на бесарабските българи, който се празнува три дни (6-8 януари) и е посветен на раждането на Христос, поради което е известен и като Рождество Христово (25 декември). Направен е опит да се систематизират и проучат особеностите на културния диалект, свързани с коледната обредност, характерните за него езикови средства от всички равнища на езиковата система, както и как те функционират в художествената практика на поколенията.

Ключови думи: Коледа, коледни обичаи и обреди, коледарска благословия, етнолингвистика, културен диалект на българина, българска диаспора в Украйна, коледни обичаи и обреди

$\triangle$ Доч. д-р Светлана Георгиева

Одески национален университет „И. И. Мечников“

Французки булевард, 24/26, гр. Одеса, 65058, Украйна

$\triangle$ Assoc. Prof. Svetlana Georgieva, PhD

Odesa I. I. Mechnikov National University 24/26, Frantsuzky Blvd., Odesa, 65058, Ukraine 